\title{
ANALISIS PERAN JAKSA PENUNTUT UMUM DALAM MENETAPKAN SURAT DAKWAAN PERKARA TINDAK PIDANA NARKOTIKA BERDASARKAN PERATURAN JAKSA AGUNG REPUBLIK INDONESIA
}

\author{
Pandu Winata \\ Universitas Serang Raya, Indonesia, pandusihombing9@ gmail.com \\ Fuqoha \\ Universitas Serang Raya, Indonesia, fuqoha23@gmail.com \\ Rokilah \\ Universitas Serang Raya, Indonesia, ilameidyfaihaazis@gmail.com
}

\begin{abstract}
Narcotics crime is a form of law violation and violation of social norms that have existed for a long time and it is very difficult for a country to eradicate it. Along with the increase in narcotics crime, it is necessary to have an eradication effort from law enforcement officers, namely the Police and the Prosecutor's Office. The police are given the authority to prevent and eradicate criminal acts and become the spearhead in the initial position of implementing the justice system. The Prosecutor's Office as one of the pillars of law enforcement in Indonesia has a heavy duty in enforcing the rule of law in Indonesia comprehensively as regulated in Law no. 16 of 2004. This study aims to find out how the Public Prosecutor in determining the indictment against the perpetrators of criminal acts of narcotics abuse starting from the consideration of determining the article used, determining the form of indictment, and the obstacles experienced by the prosecutor. The method used in this research is qualitative. The results of this study indicate that the indictment has an important role in uncovering a criminal event in the trial because it is the scope of examination for the judge.
\end{abstract}

Keywords : narcotics, public prosecutor, indictment

\begin{abstract}
Abstrak
Tindak pidana Narkotika merupakan bentuk pelanggaran hukum dan pelanggaran norma sosial yang telah ada sejak lama dan sangatlah sulit bagi suatu negara untuk memberantasnya. Seiring meningkatnya kejahatan narkotika, maka diperlukan adanya upaya pemberantasan dari aparat penegak hukum yakni Kepolisian dan Kejaksaan. Kepolisian yang diberikan kewenangan untuk melakukan pencegahan dan pemberantasan tindak pidana dan menjadi ujung tombak dalam posisi awal pelaksanaan sistem peradilan. Kejaksaan sebagai salah satu pilar penegak hukum di Indonesia yang memiliki tugas berat dalam menegakkan supremasi hukum di Indonesia secara komprehensif sebagaimana diatur dalam Undang-undang No. 16 Tahun 2004. Penelitian ini bertujuan untuk mengetahui bagaimana Jaksa Penuntut Umum dalam menetapkan surat dakwaan terhadap pelaku tindak pidana penyalahgunaan narkotika dimulai dari pertimbangan penetapan pasal yang digunakan, penentuan bentuk dakwaan, serta hambatan yang dialami jaksa. Metode yang digunakan dalam penelitian ini adalah kualitatif. Hasil penelitian ini menunjukan bahwa surat dakwaan memiliki peran penting dalam mengungkap suatu peristiwa pidana dalam persidangan karena merupakan ruang lingkup pemeriksaan bagi hakim.
\end{abstract}

Kata Kunci : Narkotika, Penuntut Umum, Surat Dakwaan 


\section{Pendahuluan}

Penegakan hukum merupakan alasan

penting dapat dijalankannya suatu negara agar meminimalisir kriminal serta tindakan kejahatan terhadap warga negaranya terutama dalam hal ini adalah penegakan hukum di Indonesia yang berkaitan dengan narkotika yang dapat membahayakan generasi muda di Indonesia. Tindak Pidana Narkotika merupakan bentuk pelanggaran hukum dan pelanggaran norma sosial yang telah ada sejak lama dan sangatlah sulit bagi suatu negara untuk memberantasnya. Meningkatnya jumlah penduduk di Indonesia yang semakin bertambah serta berkembangnya ilmu pengetahuan dan teknologi, dapat mempengaruhi perkembangan masyarakat yang semakin modern saat ini baik secara positif maupun negatif. Hal ini dapat menyebabkan timbulnya kejahatan yang terjadi di kalangan masyarakat, salah satunya penyalahgunaan narkotika, dimana para oknum memanfaatkan orang untuk memperjual belikan obat-obat terlarang tersebut. Penyalahgunaan Narkotika sekarang ini sudah sampai dalam kondisi yang sangat memprihatinkan. Narkotika dan Psikotropika merupakan obat atau bahan yang bermanfaat di bidang pengobatan, pelayanan kesehatan, dan pengembangan ilmu pengetahuan, dan pada sisi lain dapat menimbulkan ketergantungan yang sangat merugikan apabila dipergunakan tanpa pengendalian, pengawasan yang ketat dan seksama. $^{1}$

Narkotika yang semula diperlukan untuk pengobatan, dalam perkembangannya justru menyebabkan kecanduan terhadap penderita atau korban. oleh karena itu dengan adanya kejahatan yang ancamannya besar bagi pengguna narkotika dikalangan masyarakat, sangat diperlukan peranan aparat hukum khususnya kejaksaan dengan

1 Muhammad Yamin, Tindak Pidana Khusus, Cetakan Pertama, Pustaka Setia, Bandung, 2012, hlm. 163. 
bantuan oleh pihak kepolisian yang dimana bekerja sama serta bertanggungjawab untuk memberantas kejahatan Tindak Pidana Narkotika. Dengan adanya perkembangan dari peraturan undang-undang kejaksaan tersebut, maka setiap lembaga Negara wajib dilindungi oleh hukum selama menjalankan tugas, pokok dan fungsinya (tupoksi) tanpa terkecuali Polisi, Jaksa Penuntut Umum, dan Hakim. Namun, jika dalam menjalankan tupoksinya tidak sesuai menurut mekanisme aturan hukumnya, artinya hukum acara pidana (Kitab Undang-Undang Hukum Acara Pidana) yang berlaku dilanggar, maka tindakan hukum aparat penegak hukum yang menetapkan seseorang menjadi tersangka harus batal demi hukum atau dapat dibatalkan oleh putusan hakim lewat pengujian praperadilan. Hal ini penting diperhatikan untuk menjaga dan melindungi hak asasi tersangka dari kesewenangwenangan aparat penegak hukum itu sendiri. $^{2}$

2 Binsar M.Gultom, Pandangan Kritis Seorang

$$
\text { Kejaksaan dalam melaksanakan }
$$
tugasnya hendaknya merdeka dan terlepas dari pengaruh kekuasaan pemerintahan dan kekuasaan lainnya dalam upaya untuk mewujudkan kepastian hukum, ketertiban hukum, keadilan dan kebenaran dengan menghindarkan norma-norma keagamaan, kesopanan, dan kesusilaan, serta wajib menggali nilai-nilai kemanusiaan, hukum, dan keadilan yang hidup dalam masyarakat. Yang mendasar sebagai kedudukan Kejaksaan adalah menguatkan kedudukan Kejaksaan sebagai lembaga pemerintahan yang melaksanakan kekuasaan negara di bidang penuntutan. ${ }^{3}$

Kitab Undang-Undang Hukum Acara Pidana juga mengatur bahwa lembaga Kejaksaan merupakan pengendali perkara dan yang dapat menentukan apakah berkas perkara yang ada sudah dapat dikirimkan ke

Hakim Dalam Penegakan Hukum Di Indonesia, Polemik Profesi Hakim sebagai Pejabat Negara dan Pembagian Kekuasaan Kehakiman, PT.Gramedia, Jakarta, 2017, hlm. 76.

${ }^{3}$ Yesmil Anwar \& Adang, Sistem Peradilan Pidana, Widya Padjadjaran, Bandung, 2011, hlm. 204. 
Pengadilan atau belum. Kejaksaan juga merupakan satu-satunya instansi pelaksana putusan pidana. Jaksa diberikan wewenang sebagai Penuntut Umum serta melaksanakan putusan pengadilan dan wewenang lain berdasarkan Undang-Undang. ${ }^{4}$

Jaksa yang berperan sebagai Penuntut Umum harus terlepas dari pengaruh kekuasaan manapun karena untuk mencapai suatu tujuan dalam menegakkan hukum dan dituntut untuk menjalankan tugas dan wewenangnya sesuai dengan undang-undang. Serta menegakkan supremasi hukum, perlindungan kepentingan umum, penegakan hak asasi manusia,serta pemberantasan korupsi, kolusi dan nepotisme. ${ }^{5}$ Yaitu melakukan penuntutan terhadap pelaku tindak pidana narkotika dan meminta kepada hakim untuk memutus perkara tersebut.

4 Marwan Effendi, Kejaksaan RI Posisi dan Fungsinya dari Perspektif Hukum, Gramedia Pustaka Utama, Jakarta, 2005, hlm. 105.

${ }^{5}$ Ibid., hlm. 202.
Tindakan penuntutan merupakan tahapan proses pemeriksaan atas suatu tindak pidana yakni melanjutkan menyelesaikan tahap pemeriksaan penyidikan ketingkat proses pemeriksaan pada sidang pengadilan oleh hakim, guna mengambil putusan atas perkara tindak pidana yang bersangkutan, akan tetapi sebelum menginjak kepada taraf proses pelimpahan dan proses pemeriksaan disidang pengadilan, penuntut umum lebih dulu mempelajari berkas hasil pemeriksaan penyidikan apakah sudah sempurna atau belum, jika sudah cukup sempurna barulah penuntut umum mempersiapkan surat dakwaan dan surat pelimpahan perkara kepada pengadilan. Oleh karena itu, sebelum sampai kepada pelimpahan dan pemeriksaan pengadilan, tugas pokok penuntut umum adalah mempersiapkan Surat Dakwaan. ${ }^{6}$

Surat dakwaan ialah suatu surat yang diberi tanggal dan ditanda tangani oleh penuntut umum yang memuat uraian tentang

\footnotetext{
${ }^{6}$ M. Yahya Harahap, Pembahasan Permasalahan dan Penerapan KUHAP Penyidikan dan Penuntutan, Sinar Grafika, Jakarta, 2009, hlm. 386.
} 
identitas lengkap terdakwa, perumusan tindak pidana yang didakwakan yang dipadukan dengan unsur-unsur tindak pidana sebagaimana dirumuskan dalam ketentuan pidana yang bersangkutan, disertai uraian tentang waktu dan tempat tindak pidana yang dilakukan oleh terdakwa, surat mana yang menjadi dasar dan batas ruang lingkup pemeriksaan di sidang pengadilan. $^{7}$

Dapat diuraikan, bahwa terdakwa hanya dapat di pidana jika terbukti telah melakukan delik yang disebutkan dalam surat dakwaan. Jika terdakwa menurut pendapat hakim terbukti melakukan tindak pidana tetapi tidak disebutkan dalam surat dakwaan, maka kesalahan pada penyusunan surat dakwaan yang dibuat oleh jaksa penuntut umum dapat menimbulkan perkara yang diputus bebas atau lepas dari segala tuntutan hukum. Di dalam penyusunan surat dakwaan harus diuraikan tentang tindak pidana yang dilakukan oleh terdakwa

7 Harun M. Husein, Surat Dakwaan Teknik Penyusunan fungsi dan permasalahannya, Rineka Cipta, Jakarta, 1990, hlm. 43. sejelas-jelasnya dan semua unsur yang terdapat di dalam tindak pidana tersebut harus dicantumkan. yang disimpulkan dari hasil berita acara pemeriksaan yang dibuat oleh penyidik.

\section{Rumusan Masalah}

1. Bagaimanakah peran Jaksa Penuntut Umum dalam menetapkan surat dakwaan $?$

2. Bagaimana faktor yang menjadi hambatan Jaksa Penuntut Umum dalam melakukan penyusunan surat dakwaan?

\section{Tujuan Penelitian}

1. Untuk mengetahui dan menjelaskan peran Jaksa Penuntut Umum dalam menetapkan surat dakwaan.

2. Untuk mengetahui hambatan yang dihadapi dalam menetapkan surat dakwaan dan upaya yang dilakukan Jaksa Penuntut Umum mengatasi hambatan tersebut.

\section{Metode Penelitian}


Metode pendekatan yang digunakan penulis dalam penulisan ini adalah metode penelitian yuridis empiris. Yaitu pendekatan masalah yang diteliti dengan sifat hukum yang nyata atau sesuai dengan kenyataan yang hidup didalam masyarakat dengan menggunakan alat pengumpul data berupa wawancara kepada informan. ${ }^{8}$ Studi-studi sosial tentang hukum menempatkan hukum sebagai instrumen yang digunakan masyarakat dalam mencapai suatu tujuan tertentu dan hal tersebut dapat diverifikasi dan diobservasi secara empiris. Pendekatan demikian telah mereduksi esensi hukum di dalam masyarakat. ${ }^{9}$

Data primer merupakan data yang diperoleh dari sumber utama. Data primer diperoleh dari responden dan informan serta narasumber. Sumber data dalam penelitian hukum empiris berasal dari data lapangan. Data lapangan merupakan data yang berasal

\footnotetext{
${ }^{8}$ Bambang Sunggono, Metodologi Penelitian Hukum, PT. Raja Grafindo Persada, Jakarta, 2011, hlm. 56.

9 Peter Mahmud Marzuki, Penelitian Hukum Edisi Revisi ,Prenadamedia, Jakarta, 2015, hlm. 19.
}

dari responden dan informan termasuk ahli sebagai narasumber. Sedangkan Data Sekunder, yaitu data yang telah lebih dahulu dikumpulkan dan dilaporkan oleh orang di luar peneliti sendiri, walaupun yang dikumpulkan itu sesungguhnya adalah data yang asli. Dengan kata lain, data sekunder adalah data yang diperoleh dari sumber kedua, selain dari yang diteliti yang bertujuan untuk mendukung penelitian yang dilakukan. Data sekunder dapat juga dikatakan sebagai data pelengkap yang dapat digunakan untuk memperkaya data agar dapat yang diberikan benar-benar sesuai dengan harapan peneliti dan mencapai titik jenuh. Artinya data primer yang diperoleh tidak diragukan karena juga didukung oleh data sekunder. ${ }^{10}$

Adapun alat pengumpul data dengan cara peneliti melakukan wawancara, studi pustaka, dan observasi. Menurut Arikunto

\footnotetext{
10 Samsu, Metode Penelitian Teori dan Aplikasi Penelitian Kualitatif, Kuantitatif, Mixed Methods, serta Research \& Development. Pusat Studi Agama dan Kemasyarakatan, Jambi, 2017, hlm. 95.
} 
wawancara adalah sebuah dialog yang dilakukan oleh pewawancara (interviewer) untuk memperoleh informasi dari terwawancara. Metode ini dipergunakan untuk memperoleh data melalui wawancara langsung secara terpimpin antara penulis dengan orang yang memberi informasi dengan menggunakan daftar wawancara. Daftar wawancara ini biasanya disebut Instrumen Pengumpulan Data (IPD). Wawancara ini dipakai untuk lebih mendalami data yang diperoleh dari observasi. Data yang akan dicari bersifat snowball berdasarkan temuan-temuan di lapangan. Wawancara akan berhenti sampai menemukan kejenuhan data. ${ }^{11}$ Prosedur pengambilan dan pengumpulan data diperoleh dengan cara melakukan studi kepustakaan (library research) dengan tujuan mencari konsep-konsep, teori-teori, pendapat-pendapat atau penemuanpenemuan yang relevan dengan pokok

${ }^{11}$ Suharsimi Arikunto, Prosedur Penelitian Suatu Pendekatan Praktek, Rineka Cipta, Edisi Revisi II, Jakarta, 1993, hlm. 126. permasalahan melalui peraturan perundangundangan yang berhubungan dengan Jaksa Penuntut Umum dalam menetapkan surat dakwaan guna untuk dilakukannya suatu analisis terhadap studi kepustakaan tersebut dan kaitannya dengan pembuktian tindak pidana penyalahgunaan Narkotika.

Sedangkan Menurut Nanang Martono, "observasi merupakan sebuah proses mendapatkan informasi data menggunakan panca indra. Observasi digambarkan sebagai sebuah proses yang dilakukan peneliti untuk membangun hubungan antara realitas dan asumsi teoritis mereka". ${ }^{12}$ Penelitian ini berlokasi di Kota Serang, untuk memperoleh data yang digunakan secara khusus penelitian ini dilaksanakan di Kejaksaan Negeri Kota Serang, karena dari hasil data peneliti untuk mengetahui Peran Jaksa Penuntut Umum Dalam Menetapkan Surat Dakwaan Perkara

\footnotetext{
12 Bachtiar, Metode Penelitian Hukum, Unpam Press, Tanggerang Selatan, 2018, hlm. 148.
} 
Tindak Pidana Narkotika Berdasarkan Peraturan Jaksa Agung Republik Indonesia. Jenis Penelitian data yang digunakan penulis adalah metode kualitatif, yaitu data yang diperoleh kejelasan masalah yang dibahas. Menurut moleong penelitian kualitatif adalah penelitian yang bermaksud untuk memahami penomena tentang apa yang dialami oleh subjek penelitian misalnya perilaku, persepsi, motivasi, tindakan, dll secara holistic, dan dengan cara deskripsi dalam bentuk kata-kata dan bahasa, pada suatu konteks khusus yang alamiah dan dengan memanfaatkan berbagai metode alamiah. ${ }^{13}$ Tujuan digunakannya analisis kualitatif ini adalah untuk mengetahui peran jaksa penuntut umum dalam menetapkan surat dakwaan perkara tindak pidana narkotika berdasarkan peraturan jaksa agung republik Indonesia.

Hasil Penelitian Dan Pembahasan

\footnotetext{
${ }^{13}$ Moleong, Metodologi Penelitian Kualitatif, Media
} Kita, Bandung, 2005, hlm.39.

\section{Peran Jaksa Penuntut Umum}

Dalam Menetapkan Surat

\section{Dakwaan}

Di dalam Undang-Undang Nomor 16 Tahun 2004 tentang kejaksaan telah dijelaskan pengertian jaksa dan jaksa penuntut umum. Jaksa dalam rangka mempersiapkan surat dakwaan, diberikan kewenangan mengadakan prapenuntutan dalam arti melakukan penelitian terhadap berkas perkara yang diterimanya dari penyidik serta memberi petunjuk-petunjuk kepada penyidik. Dengan kata lain, hasil penyidikan adalah dasar dalam pembuatan suatu surat dakwaan. Rumusan-rumusan dalam surat dakwaan pada hakikatnya tidak lain dari pada hasil penyidikan. Surat dakwaan menempati posisi sentral dan strategis dalam pemeriksaan perkara pidana di pengadilan, karena itu surat dakwaan sangat dominan bagi keberhasilan 
pelaksanaan tugas penuntutan. Berdasarkan Pasal 1 ayat 2 UndangUndang Republik Indonesia Nomor 16 Tahun 2004 tentang Kejaksaan (selanjutnya disebut Undang-Undang Kejaksaan) pengertian penuntut umum adalah jaksa yang diberi wewenang oleh Undang-Undang untuk melakukan penuntutan dan melaksanakan penetapan hakim. Sebagai salah satu aparat penegak hukum, penuntut umum diberi wewenang khusus dalam menjalankan tugas dan fungsinya, sebagaimana yang terdapat dalam pasal 14 KUHAP diantaranya yaitu membuat surat dakwaan dan melakukan penuntutan.

Norma Pasal 1 ayat 9 UndangUndang Administrasi Pemerintahan memberikan pengertian Diskresi adalah Keputusan dan/atau Tindakan yang ditetapkan dan/atau dikeluarkan oleh Pejabat Pemerintahan untuk mengatasi persoalan konkret yang dihadapi dalam penyelenggaraan pemerintahan dalam hal peraturan perundang-undangan yang memberikan pilihan, tidak mengatur, tidak lengkap atau tidak jelas, dan/atau adanya stagnasi pemerintahan. Diskresi hanya dapat dilakukan oleh Pejabat Pemerintahan yang berwenang. Setiap penggunaannya diskresi memiliki tujuan yaitu :

1. melancarkan penyelenggaraan pemerintahan;

2. mengisi kekosongan hukum;

3. memberikan kepastian hukum;

4. mengisi stagnasi pemerintahan dalam keadaan tertentu guna kemanfaatan dan kepentingan umum.

Berdasarkan ketentuan Pasal 35 huruf c Undang-Undang Nomor 16 Tahun 2004 tentang Kejaksaan Republik Indonesia, diskresi yang melekat pada lembaga Kejaksaan berupa diskresi penuntutan 
(prosecutorial discretion), dimana kewenangan mengesampingkan perkara demi kepentingan umum dengan berlandaskan asas oportunitas hanya dimiliki oleh Jaksa Agung. Asas oportunitas bukan merupakan hal baru dalam sistem hukum acara pidana di Indonesia khususnya dalam penerapan wewenang seponeering Jaksa Agung. Persoalan asas oportunitas telah terkandung dalam Peraturan Pemerintah Pengganti UndangUndang Nomor 24 Tahun 1960 tentang Pengusutan, Penuntutan dan Pemeriksaan Tindak Pidana Korupsi. Menurut Andi Zainal Abidin Farid yang menyatakan bahwa wewenang Jaksa Agung untuk mengesampingkan perkara demi kepentingan umum berdasarkan asas oportunitas termasuk beleidsrvijheid, maka ukuran yang dapat dipakai untuk menentukan kebijakan atau penggunaan seponeering dapat juga mengacu pada asas-asas umum pemerintahan yang baik. ${ }^{14}$ Artinya diskresi yang dilandasi asas oportunitas penting bagi Jaksa agar tidak tegak lurus dalam melaksanakan kewenangannya, dikarenakan subjek dalam berhukum adalah masyarakat. Faktor sosiologis (masyarakat) menjadi tolak ukur apakah hukum memiliki nilai keadilan maupun kemanfaatan atau tidak pada saat hukum tersebut ditegakkan. Jaksa sebagai salah satu pengemban hukum yang terikat undangundang selain mutlak memiliki ketajaman berpikir, juga harus memiliki rasa kesusilaan yang halus untuk menangkap rasa keadilan di masyarakat.

Dalam Pasal 263 Kitab UndangUndang Hukum Acara Pidana mengatur tentang upaya hukum luar biasa yang dinamakan peninjauan kembali, dalam pelaksanaannya masih menimbulkan pendapat kontroversial. Karena dalam

\footnotetext{
${ }^{14}$ Andi Zainal Abidin Farid, Bunga Rampai Hukum Pidana I, Sinar Grafika, Jakarta, 1995, hlm. 96.
} 
kenyataannya masih ada beberapa pakar, praktisi dan pengamat hukum yang berpendapat bahwa yang dapat mengajukan Peninjauan Kembali adalah terpidana atau ahli warisnya pasal 263 ayat 1 Kitab Undang Hukum Acara Pidana, sedangkan jaksa penuntut umum justru bertindak untuk dan atas nama negara dan secara sekaligus mewakili korban kejahatan dianggap tidak berhak mengajukan upaya hukum peninjauan kembali. ${ }^{15}$

Upaya hukum luar biasa yaitu permintaan Peninjauan Kembali dapat ditemukan dalam pasal 263 sampai 269 Kitab Undang-Undang Hukum Acara Pidana. Berdasarkan pasal 263 ayat 1 dan 2 Kitab Undang-Undang Hukum Acara Pidana, secara tersurat memang dinyatakan bahwa yang dapat mengajukan Peninjauan Kembali adalah terpidana atau ahli warisnya. Akan

${ }^{15}$ HMA Kuffal, Penerapan KUHAP Dalam Praktik Hukum, UMM press, Malang, 2007, hlm. 232. tetapi berdasarkan pasal 263 ayat 3 Kitab Undang Hukum Acara Pidana ternyata selain terpidana atau ahli waris, masih ada pihak lain yang dapat mengajukan upaya hukum Peninjauan Kembali yaitu pihak lain memang secara eksplisit tidak disebutkan akan tetapi pihak lain tersebut tidak lain adalah jaksa penuntut umum, terhadap suatu putusan pengadilan yang telah memperoleh kekuatan inckracht yang dalam diktumnya atau bunyinya menyatakan "perbuatan yang didakwakan telah terbukti akan tetapi tidak diikuti suatu pemidanaan". ${ }^{16}$

Dalam putusan tersebut terdakwa tidak dijatuhi hukum atau putusan pidana meskipun terdakwanya telah dinyatakan telah terbukti atau bersalah, oleh karena itu dalam hal ini jaksa penuntut umum memiliki hak mengajukan Peninjauan Kembali, terpidana sudah dinyatakan bersalah

\footnotetext{
${ }^{16}$ Ibid., hlm. 233.
} 
namun tetap tidak dihukum. Artinya pihak-pihak yang bersangkutan dapat mengajukan peninjauan kembali kepada Mahkamah Agung, apabila terdapat hal atau keadaan tertentu yang ditentukan dalam UndangUndang. Upaya hukum adalah langkah untuk mengkoreksi kinerja hakim atas putusan yang dibuat dan langkah lanjutan bagi para pencari keadilan dengan memanfaatkan upaya hukum tersebut.

Terdapat peninjauan kembali yang ditempuh dengan adanya novum. Bahwa yang dimaksud dengan "hal atau keadaan tertentu" antara lain adalah ditemukannya bukti baru (novum). Dalam suatu peninjauan kembali, novum berperan penting dalam diterima tidaknya pengajuan peninjauan kembali. Novum dalam perkara pidana disebut dengan "keadaan baru" terdapat dalam Pasal 263 ayat 2 huruf a Kitab UndangUndang Hukum Acara Pidana. Novum adalah adanya suatu keadaan baru yang menimbulkan dugaan kuat, jika diketahui keadaan itu pada waktu sidang masih berlangsung hasilnya akan berupa putusan bebas atau lepas dari tuntutan hukum atau tuntutan penuntut umum tidak dapat diterima dan juga terhadap perkara itu diterapkan ketentuan pidana yang lebih ringan. Apakah novum diajukan sudah sesuai dengan perundang-undangan yang ada atau alasan peninjauan kembali tersebut sudah memenuhi persyaratan. Hak jaksa mengajukan upaya hukum peninjauan kembali secara hukum formil tidak di atur dalam Undang-Undang Nomor 8 Tahun 1981 tentang Kitab UndangUndang Hukum Acara Pidana, akan tetapi jaksa penuntut umum untuk melakukan upaya hukum hanya diatur dalam upaya hukum, banding dan kasasi demi kepentingan hukum, pasal 259 ayat 1 Kitab Undang-Undang Hukum 
Acara Pidana dan pasal 35 huruf d Undang-Undang No 16 Tahun 2004 Tentang Kejaksaan Republik Indonesia untuk Peninjauan Kembali sendiri secara hukum formil tidak di atur, akan tetapi dalam praktik jaksa penuntut umum mempunyai hak untuk mengajukan Peninjauan Kembali untuk kepentingan umum, negara, korban dan pihak ketiga, memang dalam Kitab Undang-Undang Hukum Acara Pidana untuk hak korban dan pihak ketiga tidak diberi ruang atau tidak diatur dalam Kitab Undang Hukum Acara Pidana, oleh karena itu jaksa penuntut umum memiliki hak untuk mengajukan Peninjauan Kembali walaupun secara hukum formil jaksa penuntut umum tidak boleh, akan tetapi atas dasar keadilan dan keseimbangan jaksa penuntut umum memiliki hak yang sama seperti terpidana atau ahli warisnya.
Kedudukan jaksa sebagai penuntut umum dalam Kitab UndangUndang Hukum Acara Pidana sebagai aparat penegak hukum berwenang melakukan penuntutan didalam pasal 1 ayat 7 dan pasal 137. Artinya dalam posisi sebagai aparat penuntut umum, pasal 140 ayat 1 menegaskan wewenang penuntut umum untuk membuat surat dakwaan. Tujuan utama surat dakwaan adalah bahwa undang-undang ingin melihat ditetapkannya alasan-alasan yang menjadi dasar tuntutan tindak pidana yang telah dilakukan itu harus dicantumkan dengan sebaik-baiknya. Terdakwa dipersalahkan karena telah melanggar suatu aturan hukum pidana, pada suatu saat dan tempat tertentu serta dinyatakan pula keadaan-keadaan sewaktu melakukan tindak pidana.Menyebutkan waktu (tempus) dan tempat (locus delecti) serta keadaan menunjukan kepada dakwaan terhadap 
peristiwa-peristiwa dan perbuatanperbuatan tertentu, yang dispesialisasi dan di induvidualisasi. ${ }^{17}$

Surat dakwaan merupakan surat atau akte yang memuat perumusan tindak pidana yang didakwakan kepada terdakwa, perumusan mana ditarik dan disimpulkan dari hasil pemeriksaan penyidikan dihubungkan dengan rumusan pasal tindak pidana yang dilanggar dan didakwakan pada terdakwa, dan surat dakwaan tersebutlah yang menjadi dasar pemeriksaan bagi hakim dalam sidang pengadilan. Sebagai suatu akta, surat dakwaan memiliki fungsi yang sangat dominan dalam proses pidana.

Adapun fungsi surat dakwaan yaitu :

1. Bahwa dalam pemeriksaan sidang, pemeriksaan itu dibatasi oleh faktafakta perbuatan yang didakwakan oleh penuntut umum dalam surat

17 Martiman Prodjohamidjojo, Teori dan Teknik Membuat Surat Dakwaan, Ghalia Indonesia, Bogor, 2002, hlm. 32. dakwaan yang menjadi dasar pemeriksaan sidang tersebut.

2. Bahwa hakim dalam menjatuhkan putusannya harus semata-mata didasarkan pada hasil pemeriksaan dan penilaian terhadap fakta-fakta yang didakwakan dalam surat dakwaan.

3. Bahwa keseluruhan isi dakwakan yang terbukti dipersidangan merupakan dasar pertimbangan hakim dalam menjatuhkan putusan.

Didalam surat dakwaan fakta dan keadaan bukan merupakan syarat materil maupun syarat formil. Tanpa menyebutkan fakta dan keadaan dalam surat dakwaan, tidak mengurangi sahnya surat dakwaan. Namun demikian, sebaiknya surat dakwaan sedapat mungkin memuat fakta dan keadaan yang meliputi tindak pidana yang didakwakan. Uraian fakta dan keadaan yang lengkap dalam surat 
dakwaan, lebih memberi penjelasan bagi terdakwa dan hakim tentang fakta dan keadaan secara sempurna dan lengkap, tidak mengakibatkan batal surat dakwaan. Hal ini ditegaskan dalam suatu putusan Mahkamah Agung tanggal 23 Agustus 1969 No. 36 $\mathrm{K} / \mathrm{Kr} / 1968$ yang memuat kaidah, "walaupun surat tuduhan tidak menyebutkan fakta dan keadaan yang menyertai perbuatan yang dituduhkan tidak secara lengkap tergambar, tidak dengan sendirinya mengakibatkan batalnya putusan". Hal ini menimbulkan permasalahan dalam praktek, karena Kitab Undang-Undang sendiri tidak menggariskan secara garis besar. Didalam pasal 143 ayat 2 tidak mencantumkan fakta dan keadaan sebagai syarat materil. Oleh karena itu, menilai surat dakwaaan yang tidak secara lengkap memuat fakta dan keadaan, dapat dipedomani putusan
Mahkamah Agung yang dikemukakan. Akan tetapi agar jangan keliru, harus dibedakan pengertian fakta atau keadaan dengan "cara melakukan" tindak pidana. Cara melakukan tindak pidana termasuk syarat materiil surat dakwaan, misalnya terdakwa didakwa membunuh tetapi surat dakwaan tidak menyebut secara jelas bagaimana cara pembunuhan yang dilakukan terdakwa.

Dakwaan yang demikian kabur sehingga persidangan tidak tahu arah bagaimana membuktikan kesalahan terdakwa. Berbeda dengan mengenai fakta dan keadaan. Fakta atau keadaan lebih mendekati masalah pembuktian dan yang berhubungan dengan hal yang memberatkan hukuman. Oleh karena mengenai hal ini lebih dekat kepada masalah alat pembuktian maka fakta 
atau keadaan ini dapat dikemukakan jaksa dalam persidangan. ${ }^{18}$

Dalam merumuskan dakwaan jaksa penuntut umum mesti cermat supaya tidak ada lubang bagi terdakwa untu terlepas dari pertanggung jawaban hukum atas tindak pidana yang dilakukannya. Terutama penyusunan surat dakwaan yang berupa peristiwa pidana yang bersifat perbarengan antara beberapa ketentuan pidana (lebih dari satu aturan pidana yang terlanggar atau eendaadshe samenloop), harus hati-hati membedakannya dengan perumusan dakwaan yang bersifat "perbuatan berlanjut" atau vorgezet tehandeling maupun dengan peristiwa pidana yang bersifat concursus realis atau perbarengan perbuatan (meerdaadsche sameloop). ${ }^{19}$

${ }^{18}$ M. Yahya Harahap, Pembahasan Permasalahan dan Penerapan KUHAP Penyidikan dan Penuntutan, Edisi Kedua, Sinar Grafika, Jakarta, 2014, hlm. 395.

${ }^{19}$ Ibid., hlm. 397.
Jaksa penuntut umum dalam hal untuk menentukan jenis dakwaan yang disangkakan ialah dakwaan alternatif karna alasan fleksibilitasnya, untuk menjerat terdakwa kedalam pasal berlapis. Dalam prakteknya dakwaan subsidair tersebut, disebut juga dakwaan alternatif karena umumnya dakwaan disusun oleh jaksa penuntut umum menurut bentuk subsidiar. Dakwaan alternatif yaitu dalam satu kalimat tercantum dua atau lebih perbuatan yang didakwakan yang saling mengecualikan, misalnya, dakwaan perbuatan yang dilakukan oleh terdakwa telah direncanakan terlebih dahulu, disinilah dakwaan tersebut bersifat alternatif yang sesungguhnya dan disinilah hakim dapat memilih perbuatan yang direncanakan dan yang tidak direncanakan yang telah terbukti. Dasar pertimbangan penggunaan surat dakwaan alternatif adalah karena jaksa 
penuntut umum belum yakin benar tentang kualifikasi tindak pidana atau pasal yang tepat untuk diterapkan pada tindak pidana tersebut. Untuk memperkecil peluang lolosnya terdakwa dari dakwaan, maka digunakan dakwaan alternatif atau pilihan. Segi positif dalam dakwaan alternatif ini adalah bahwa terdakwa tidak mudah untuk lolos dari dakwaan dan pembuktian lebih sederhana. Oleh karena itu, penuntut umum membuat dakwaan secara berlapis dengan cara tindak pidana yang ancaman pokoknya lebih tinggi ditempakan di lapisan atas dan tindak pidana yang ancaman lebih rendah ditempatkan dibagian bawah secara berurut. Segi negatifnya terdakwa akan lebih sulit mempersiapkan pembelaannya, serta dapat menimbulkan kesan bahwa penuntut umum kurang atau tidak memahami secara pasti tentang materi perkara yang bersangkutan. Bentuk surat dakwaan dipergunakan apabila suatu akibat yang ditimbulkan suatu tindak pidana menyentuh atau menyinggung beberapa tindak pidana. Keadaan tersebut dapat menimbulkan keraguan bagi penuntut umum, baik mengenai kualifikasi tindak pidanannya maupun mengenai pasal yang dilanggarnya.

Jaksa penuntut umum dalam menetapkan surat dakwaan sudah merupakan hasil akhir, ketika jaksa penuntut umum sudah membuat surat dakwaan terhadap tersangka atau pelaku penyalahguna narkotika dari hasil akhir penyidikan. Yang menjadi titik awal jaksa penuntut umum dalam menetapkan pelaku sebagai penyalahguna narkotika, bukan didalam surat dakwaan tetapi didalam penelitian berkas perkara. Jadi dalam tahapan dari berkas perkara baru ketika berkas 
perkara tersebut sudah lengkap, barulah dituang dalam surat dakwaan sehingga surat dakwaan tersebut sebagai hasil akhir dari penelitian berkas perkara dari penyidikan..$^{20}$

Bahwa penetapan penyalahguna narkotika bukan dari surat dakwaan melainkan didalam berkas perkara. Berkas perkara yang diteliti oleh jaksa penuntut umum dan jaksa penuntut umum meneliti bahwa ada kemungkinan pelaku atau tersangka sebagai penyalahguna narkotika berdasarkan syarat syarat. Syarat tersebut terdapat dalam berkas perkara yang dibuat penyidik kepolisian adalah :

1. Terdapat barang bukti narkotika jenis sabu dibawah 1 gram.

2. Hasil tes urine positif narkotika.

$$
\begin{array}{clc}
\text { Dan } & \text { itulah } & \multicolumn{2}{c}{\text { syarat-syarat }} \\
\text { penyalahguna } & \text { narkotika pada saat }
\end{array}
$$

\footnotetext{
${ }^{20}$ Hasil wawancara dengan Bapak Budi Atmoko,SH selaku Jaksa Anggota Bagian Seksi Tindak Pidana Umum Kejaksaan Negeri Serang tanggal 04 Agustus 2021 jam 09.00 Wib
}

penelitian berkas perkara. Ketika berkas perkara terdapat barang bukti narkotika terutama jenis sabu dibawah 1 gram dan hasil tes urine positif, hasilya akan dituang didalam surat dakwaan sebagai penyalahguna narkotika. Bentuk surat dakwaan sebagai penyalahguna narkotika, dengan adanya hasil urine positif dan barang bukti dibawah 1 gram memang diduga sangat kuat, akan tetapi jaksa penuntut umum akan melapisinya dengan pasal 112 undang-undang narkotika dan membuat surat dakwaan tersebut dalam bentuk surat dakwaan alternatif bukan surat dakwaan subsider. Jaksa penuntut umum dalam menyusun surat dakwaan berdasarkan hasil penyidikan polisi didalam berkas perkara, artinya putusan bebas tersebut bukan berdasarkan surat dakwaan tetapi jaksa penuntut umum tidak dapat membuktikan surat dakwaan, sehingga alat bukti yang dihadirkan didepan 
persidangan pada pembuktian tidak mendukung terhadap surat dakwaan yang dibuat jaksa penuntut umum. Jadi yang didakwakan penyalahguna tetapi yang dibuktikan didepan persidangan, misalnya hasil tes urine ternyata negatif dan barang buktinya ternyata diatas 1 gram, oleh karna itu bukan penyalahguna artinya tidak terbukti penyalahguna, maka dakwaan penyalahguna dinyatakan bebas dari tuntutan hukum.

$$
\text { Jaksa penuntut umum }
$$

sebenarnya memiliki kewenangan dan tanggung jawab terhadap berkas perkara. Berkas perkara tersebut menjadikan tanggung jawab penyidik tetapi tanggung jawab jaksa penuntut umum juga, ketika berkas perkara tidak lengkap yang harus aktif meminta supaya penyidik melengkapi, seharusnya jaksa penuntut umum. Bukan sebenarnya beban dari penyidik kecuali memang penyidik tidak sanggup menyelesaikan berkas perkara tersebut sudah menjadi tanggung jawab penyidik ketika jaksa penuntut umum sudah mendorong penyidik untuk melengkapi, tetapi penyidik tidak melengkapi karena sudah menjadi tanggung jawab penyidik. Tetapi ketika jaksa penuntut umum mengabaikan berkas perkara, kekurangan berkas perkara yang diajukan dalam pasal 127 syarat tersebut dibawah 1 gram dan hasil urine positif. Apabila jaksa penuntut umum melalaikan atau sengaja tidak mau meminta penyidik untuk melengkapi urine positif dan ditimbang dibawah 1 gram sudah menjadi tanggung jawab dari jaksa penuntut umum sebagai pengendali suatu perkara.

\section{Hambatan Jaksa Penuntut Umum} Dalam Melakukan Penyususan Surat Dakwaan 
Faktor penghambat penyusunan

surat dakwaanFaktor yang menjadi

hambatan jaksa penuntut umum, kelengkapan formil dan materil dalam berkas perkara yang tidak sepenuhnya dilengkapi oleh penyidik, ketika penyidik tidak melengkapi berkas perkara tersebut, jaksa penuntut umum terkendala dalam membuat surat dakwaan. Pada intinya dalam mengenai sempurnanya surat dakwaan tersebut harus terdiri lengkap dari syarat formil.

\section{Identitas terdakwa}

2. Riwayat penahanan terdakwa

Adapun syarat materiil menurut

Pasal 143 ayat (2) huruf b KUHAP, bahwa surat dakwaan harus memuat uraian "secara cermat, jelas, dan lengkap mengenai tindak pidana yang didakwakan dengan menyebutkan waktu (tempus delicti) dan tempat pidana itu dilakukan (locus
delicti).Surat dakwaan tidak tersusun secara sempurna.

Upaya Jaksa Penuntut Umum dalam meminimalisir kesalahan dalam penyusunan surat dakwaan. Ketika surat dakwaan itu tidak sempurna dalam pembuktian surat dakwaan tersebut bermasalah akan terkendala pada pembuktian yang akhirnya beresiko terhadap putusan bebas atau lepas dari tuntutan.Artinya jaksa penuntut umum tidak teliti dalam mempelajari berkas perkara, sehingga terdapat ada fakta baru didalam berkas perkara yang perlu dikembangkan jaksa penuntut umum ketika barang bukti yang awalnya pada saat pengiriman pertama hasil urinenya positif tetapi barang bukti tersebut belum dinyatakan terbukti, sehingga jaksa penuntut umum mengirim berkas perkara petunjuk supaya diteliti lebih lanjut barang bukti berapa gramnya. 
Bahwa pengembangan penyidikan harus di gali lebih lanjut oleh penyidik. ${ }^{21}$

Dalam proses pembuatan surat dakwaan tersebut penuntut umum memiliki berbagai hambatan-hambatan dalam menyususn surat dakwaan, sehingga dapat mempengaruhi kualitas dari surat dakwaan yang hal tersebut dapat mempengaruhi dari proses dan hasil persidangan, karena surat dakwaan menempati posisi yang sentral dalam persidangan. Mengingat penuntut umum dituntut harus membuat suatu surat dakwaan yang cermat, telitit, dan tidak berbelit-belit dan surat dakwaan sendiri merupakan mahkota profesi seorang jaksa, maka tentu penuntut umum harus mempunyai upaya-upaya untuk mengatasi hambatan-hambatan yang ada dalam membuat surat dakwaan demi menjaga marwah dan menjaga

${ }^{21}$ Hasil wawancara dengan Bapak Budi Atmoko,SH selaku Jaksa Anggota Bagian Seksi Tindak Pidana Umum Kejaksaan Negeri Serang tanggal 04 Agustus 2021 jam $10.00 \mathrm{Wib}$ kehormatan profesi jaksa dan intansi

kejaksaan.

\section{Penutup}

\section{Kesimpulan}

Berdasarkan hasil penelitian dan wawancara yang telah dianalisis, maka dapat ditarik kesimpulan sebagai berikut:

a. Surat dakwaan merupakan dasar atau landasan pemeriksaan didalam sidangan pengadilan. Hakim dalam memeriksa satu perkara pidana tidak boleh menyimpang dari apa yang dirumuskan dalam surat dakwaan. Seorang terdakwa yang dihadapkan kesidang pengadilan hanya dapat dijatuhi hukuman karena telah terbukti melakukan tindak pidana seperti yang disebutkan atau dinyatakan jaksa penuntut umum dalam surat dakwaan. Surat dakwaan yang disusun jaksa penuntut umum harus memenuhi syarat formal dan 
syarat materil sebagaimana disebutkan dalam pasal 143 ayat (2) KUHAP. Artinya Jaksa Penuntut Umum dalam menetapkan bentuk surat dakwaan dilihat berdasarkan pasal-pasal yang ditentukan karena antara satu pasal dan lainnya mengatur mengenai jenis dan kualifikasi perbuatan yang berbeda. Terlebih dahulu yang harus diperhatikan Jaksa Penuntut Umum adalah penelitian berkas perkara, terkait perbuatan terdakwa dalam melakukan tindak perkara pidana penyalahgunaan narkotika, serta unsur-unsur pasal yang ditetapkan haruslah di teliti agar memenuhi syarat formil dan syarat materill dari surat dakwaan tersebut. Sehingga Penuntut Umum dalam membuat atau menyusun surat dakwaan menyangkut pembuktian tindak pidana penyalahgunaan narkotika lebih cenderung menggunakan Pasal 112 (memiliki, menyimpan, menguasai atau menyediakan dan Menggunakan bagi diri sendiri Narkotika gol I bukan tanaman yang diduga jenis sabu) dan Pasal 127 (penyalahguna narkotika) UndangUndang Narkotika. Kedua pasal tersebut dibuat dalam bentuk surat dakwaan subsidair maupun bentuk surat dakwaan alternatif. Dari kecenderungan formulasi pasal dakwaan yang digunakan oleh Penuntut Umum tersebut dapat dikatakan bahwa pendekatan pemidanaan penjara terhadap pengguna/penyalahguna narkotika lebih dominan dibandingkan dengan menempatakan penyalahguna narkotika ke dalam lembaga rehabilitasi baik secara medis maupun sosial. Selain itu, kecenderungan pengenaan pasal 112 
UU Narkotika membawa imbas yang cukup besar bagi penahanan terhadap pengguna narkotika. Ancaman pidana pada pasal 112 UndangUndang Narkotika yang minimum 4 (empat) tahun serta maksimum 12 (dua belas) tahun.

b. Hambatan dalam penyusunan surat dakwaan yaitu berdasarkan keterangan yang diberikan oleh Jaksa Penuntut Umum di Kejaksaan Negeri Serang penyelesaian perkara Tindak Pidana penyalahgunaan narkotika, kurangnya alat bukti yang sah dan belum terdapat persamaan presepsi aparat penegak hukum. Untuk menghindari batalnya surat dakwaan maka jaksa penuntut umum dalam perumusan surat dakwaan harus dilakukan secara cermat, jelas dan lengkap menyesuai tindak pidana yang dilakukan Jaksa penuntut Umum dalam membuat surat dakwaan harus secara teliti dan saksama untuk memenuhi syarat surat dakwaan agar surat dakwaan tidak terancam dengan kebatalan baik batal demi hukum.

\section{Saran}

Berdasarkan hasil penelitian dan kesimpulan yang telah diuraikan, maka penulis memberikan saran-saran sebagai berikut:

a. Jaksa Penuntut Umum diharapkan lebih cermat dalam membuat surat dakwaan, sebagaimana diketahui betapa pentingnya peranan surat dakwaan, maka kemampuan jaksa penuntut umum dalam menyusun surat dakwaan perlu terus ditingkatkan dan sehubungan dengan itu diperlukan bimbingan serta pengendalian lebih mendalam agar jaksa penuntut umum mampu menyusun surat dakwaan secara professional, efektif dan efisien guna 
mengoptimalkan keberhasilan tugas kejaksaan dibidang penuntutan harus lebih teliti dalam menyusun surat dakwaan serta harus memperhatikan perbuatan yang telah dilakukan oleh terdakwa. Karena jika perbuatan itu tidak terbukti didalam persidangan maka terdakwa terlepas dari segala tuntutan hukum.

b. Jaksa Penuntut Umum dalam menangani perkara penyalahguna narkotika harus berkordinasi dengan penyidik, menghimbau untuk kemudian pada saat mengembalikan berkas perkara

\section{Daftar Pustaka}

\section{Buku}

Andi Zainal Abidin Farid, Bunga Rampai Hukum Pidana I, Sinar Grafika, Jakarta, 1995.

Bachtiar, Metode Penelitian Hukum, Penerbit Unpam Press, Tangerang Selatan, 2018.
Bambang Sunggono, Metodologi Penelitian Hukum, PT. Raja Grafindo Persada, Jakarta, 2011. Binsar M.Gultom, Pandangan Kritis Seorang Hakim Dalam Penegakan Hukum Di Indonesia, Polemik Profesi Hakim sebagai Pejabat Negara dan Pembagian Kekuasaan Kehakiman, PT.Gramedia, Jakarta, 2017.

HMA Kuffal. Penerapan KUHAP Dalam Praktek Hukum, UMM Press, Malang, 2007.

Harun M. Husein, Surat Dakwaan Teknik Penyusunan fungsi dan permasalahannya, Rineka Cipta, Jakarta, 1990.

Martiman Prodjohamidjojo, Teori dan Teknik Membuat Surat Dakwaan, Ghalia Indonesia, Bogor, 2002.

Marwan Effendy, Kejaksaan RI Posisi dan Fungsinya dari Perspektif 
Hukum, Jakarta, Gramedia

Pustaka Utama, 2005.

Moleong, Metodologi Penelitian

Kualitatif, Media Kita, Bandung, 2005.

Muhammad Yamin, Tindak Pidana

Khusus, cetakan pertama, Pustaka

Setia, Bandung, 2012.

M. Yahya Harahap, Pembahasan

Permasalahan dan Penerapan

KUHAP, Penyidikan dan

Penuntutan, Sinar Grafika,

Jakarta, 2014.

Peter Mahmud Marzuki, Penelitian

Hukum, Edisi Revisi,

Prenadamedia Group, Jakarta, 2015

Suharsimi Arikunto, Prosedur

Penelitian Suatu Pendekatan

Praktek, Rineka Cipta, Edisi

Revisi II, Jakarta, 1993.

Samsu, Metode Penelitian, (Teori dan Aplikasi Penelitian Kualitatif,
Kuantitatif, Mixed Methods, serta

Research \& Development), Pusat

Studi Agama dan

Kemasyarakatan

(PUSAKA)

Cetakan 1, Jambi, 2017.

Yesmil, Anwar dan Adang, Sistem Peradilan Pidana (Konsep, Komponen dan Pelaksanaannya dalam Penegakan Hukum di Indonesia), Widya Padjadjaran, Bandung, 2011.

\section{Jurnal}

Ganda Yusaf A. Kewajiban Menyampaikan Surat Dakwaan Oleh Penuntut Umum Kepada Terdakwa Atau Penasihat Hukumnya. Jurist-Diction: Vol. 2

No. 3, Mei 2019.

Ratna Sari Dewi Polontalo. Independensi Jaksa Sebagai Penuntut Umum Dalam Tindak Pidana Korupsi Menurut UndangUndang Nomor 16 Tahun 2004 
Tentang Kejaksaan Republik

Indonesia. Lex Crimen Vol.

VII/No.6 /Ags/2018.

Valentino Yoel Tendean. Batalnya

Surat Dakwaan Menurut Hukum

Acara Pidana. Lex Crimen Vol.

VII/No. 5 /Jul/2018.

\section{Peraturan Perundang-Undangan}

Kitab Undang-undang Hukum Acara

Pidana Nomor 8 Tahun 1981

tentang Hukum Acara Pidana,

(Lembaran Negara Republik

Indonesia Tahun 1981 Nomor 76,

Tambahan Lembaran Negara

Republik Indonesia Nomor 3285).

Undang-undang Nomor 16 Tahun 2004

Tentang Kejaksaan Republik

Indonesia. (Lembaran Negara

Republik Indonesia Tahun 2004

Nomor 67, Tambahan Lembaran

Negara Republik Indonesia

Nomor 4401.)
Undang-Undang Nomor 35 Tahun 2009

Tentang Narkotika, (Lembaran

Negara Republik Indonesia Tahun

2009 Nomor 143, Tambahan

Lembaran Negara Republik

Indonesia Nomor 5062.)

\section{Sumber Lainnya}

Wawancara dengan Bapak Budi Admoko, SH (Jaksa Penuntut Umum pada Kejaksaan Negeri Serang) pada hari Rabu tanggal 04 Agustus 2021 Pukul 09.00 WIB. 